\title{
Hubungan Gambaran Diri Ibu Primigravida Dengan Inisiasi Menyusu Dini di Wilayah Puskesmas Lubuk Buaya Kota Padang
}

\author{
Vetty Priscilla \\ ${ }^{a}$ Fakultas Keperawatan Unand \\ E-mail : vettypriscilla@gmail.com
}

\begin{abstract}
A Physical change is one of the changes experienced by mothers during pregnancy such as associated with self-image. It means how the mother looked at herself during pregnancy. If the mother does not adapt to these changes it will affected subsequent to maternal behaviors such as breastfeeding is not immediate. This study aims to see a correlation between selfimage of primigravida with early initiation of breastfeeding practice. This research was conducted on 32 respondents by using the cross sectional methods. Data was taken by a purposive sampling. Data were analyzed by using computerized to analize the univariate and bivariate analysis. The study was found that $90.6 \%$ mothers did not perform early initiation of breastfeeding, while $53.1 \%$ have a positive self-image during pregnancy. Then, it is a significant relationship between self-image of primigravida with giving early initiation of breastfeeding where $p=0.001$. To improve on giving early initiation of breastfeeding, mother should be given health education about the importance of breastfeeding immediately after birth.
\end{abstract}

Keywords: early initiation of breastfeeding, self image, primigravida

Perubahan fisik merupakan salah satu perubahan yang dialami ibu pada masa kehamilan seperti terkait dengan gambaran diri yaitu bagaimana ibu memandang dirinya selama kehamilan. Jika ibu tidak beradaptasi terhadap perubahan ini maka akan berpengaruh terhadap perilaku ibu selanjutnya seperti pemberian ASI yang tidak segera. Penelitian ini bertujuan untuk melihat hubungan gambaran diri pada ibu primigravida dan pemberian inisiasi menyusui dini. Penelitian ini dilakukan pada 32 responden dengan mengunakan metode korelasi dengan pendekatan cross sectional. Pengambilan sampel dilakukan secara purposive. Data diolah dengan mengunakan komputerisasi untuk melihat analisa univariat dan bivariat. Dari hasil penelitian, didapatkan bahwa 90,6\% ibu tidak melakukan inisiasi menyusui dini sedangkan 53,1\% ibu mempunyai gambaran diri positif selama kehamilan. Setelah dilakukan uji statistik didapatkan data bahwa terdapat hubungan yang signifikan antara gambaran diri dengan pemberian inisiasi menyusui dini dimana $p=0,001$. Untuk peningkatan pemberian inisiasi menyusui dini diharapakan selama masa kehamilan ibu diberikan pendidikan kesehatan tentang pentingnya pemberian ASI sesegera mungkin setelah melahirkan secara berkesinambungan.

Kata Kunci: inisiasi menyusui dini, gambaran diri, primigravida

Selama kehamilan, ibu akan mengalami perubahan fisiologis maupun psikologis pada dirinya karena perubahan hormonal dan adanya tekanan mekanis akibat membesarnya uterus dan jaringan lain (Bobak \& Jensen, 2000). Perubahan fisik selama kehamilan terlihat nyata pada organ reproduksi ibu seperti uterus dan payudara disamping melibatkan sistem-sistem tubuh lainnya termasuk psikologis ibu. Pada masa kehamilan, semua perubahan fisiologis sama pada setiap ibu, tetapi perubahan psikologis tidak akan sama karena tergantung pada kesiapan ibu tersebut menghadapi kehamilan dan bagaimana dia beradaptasi terhadap kehamilan serta pengalaman hamil sebelumnya. Perubahan bentuk tubuh yang cepat dan nyata merupakan perubahan fisiologis yang terjadi selama kehamilan. Selama trimester pertama, bentuk tubuh sedikit berubah tetapi pada trimester kedua terjadi pembesaran abdomen yang nyata dan pembesaran payudara untuk memastikan status kehamilan, keadaan ini merupakan salah satu tanda presumtif kehamilan. Akibatnya, ibu merasa seluruh tubuhnya bertambah besar. Perasaan ini akan semakin kuat seiring dengan kemajuan kehamilan dan mempengaruhi sikap ibu yang sering berubah seiring bertambahnya usia 
kehamilan. Ibu akan menunjukkan sikap positif terhadap tubuh pada trimester pertama, namun seiring bertambahnya usia kehamilan sikap tersebut menjadi lebih negatif (Bobak \& Jensen, 2000).

Perubahan bentuk

tubuh ini biasanya akan mempengaruhi konsep diri seorang ibu terutama dalam hal gambaran dirinya sendiri. Apalagi ada anggapan di masyarakat yang menekankan bahwa tubuh yang ramping akan membuat diri seseorang menarik untuk dilihat (Soetjiningsih, 2004). Gambaran diri merupakan penilaian individu terhadap dirinya atau fisiknya termasuk atribut-atribut fisik, fungsi tubuh, seksualitas, status sehatsakit dan yang kelihatan dari tubuhnya (Driever, 1976; dalam Townsend, 2003). Pada saat hamil, seorang ibu cenderung bersikap tidak percaya diri terhadap penampilan barunya tersebut. Keadaan ini bisa menimbulkan perasaan tidak menarik sehingga dapat mempengaruhi emosi atau perasaan ibu. Begitu juga menurut Dadiri (2004), ibu hamil biasanya mengeluh dan mencurigai suaminya akan kemungkinan berselingkuh. Pikiran buruk ini muncul karena adanya perasaan menjadi jelek, sehingga ibu hamil pun cendrung menjadi rendah diri. Gambaran diri pada ibu hamil bisa terlihat seperti menerima perubahan diri. Pada ibu setelah melahirkan, penerimaan dapat diidentifikasi melalui perilaku ibu seperti perilaku menyusui dini atau membiarkan bayi inisiasi menyusui dini yaitu pemberian asi dalam 30-60 menit pertama setelah melahirkan.

Hasil wawancara pada studi pendahuluan yang telah dilakukan oleh peneliti di salah satu praktek bidan swasta di Kota Padang tentang perilaku menyusui, peneliti menemukan bahwa ada tiga orang ibu primigravida yang sudah masuk fase laten kala I persalinan dan rencana melahirkan normal ada keinginan untuk menunda menyusui bayinya. Alasan yang sering dikemukan oleh mereka adalah rasa ketakutan jika berat badan mereka tidak mengalami penurunan.

\section{METODE PENELITIAN}

Desain yang digunakan pada penelitian ini adalah korelasi karena bertujuan untuk mengambarkan variabel independen dan dependen penelitian (Burns \& Grove, 1993). dengan pendekatan potong lintang (Cross Sectional). Pendekatan cross sectional adalah yang sifatnya sesaat pada suatu waktu (Sevilla, 1993; Utarini, 2000). Sedangkan menurut Pratiknya (2000) penelitian cross sectional adalah penelitian yang dilakukan tanpa suatu perlakuan terhadap responden dan bertujuan untuk mempelajari ada tidaknya hubungan antara faktor risiko (variable independen) dengan efek (variabel dependen), di mana ke dua variabel tersebut di observasi pada saat yang sama. Populasi yang digunakan dalam penelitian ini adalah ibu hamil primigravida trimester III yang berada di wilayah Puskesmas Lubuk Buaya pada Bulan Oktober -Desember 2009 berjumlah 32 orang (Laporan KIA K4 ANC, Januari 2010). Analisa data dilakukan dengan analisa univariat dengan menggunakan analisis distribusi frekuensi dan statistik deskriptif untuk melihat variasi dari variabel bebas dan variabel terikat. Hasil analisa ini ditampilkan dalam bentuk distribusi frekuensi dimana sebelumnya pada masing-masing variabel akan dicari nilai mediannya dan dilanjutkan dengan analisa bivariat. Analisis bivariat bertujuan untuk mengetahui adanya hubungan antara variabel independen dan variabel dependen (Sutanto, 2001). Uji statistik yang digunakan adalah Chi Square. Analisis bivariat juga bermanfaat untuk mengukur keeratan hubungan antara kedua variabel (Sutanto, 2001; Sabri, 1999). Derajat kepercayaan (p) yang digunakan dalam penelitian ini adalah $95 \%(\alpha=0,05)$. Jika nilai $(\mathrm{p})<0,05$ maka secara statistik disebut bermakna dan jika nilai $(p)>0,05$ maka hasil perhitungan tersebut tidak bermakna.

\section{HASIL DAN PEMBAHASAN}

Dari penelitian yang telah dilakukan, maka didapatkan analisa univariat dan bivariat sebagai berikut: 


\begin{tabular}{|l|c|c|}
\hline \multicolumn{1}{|c|}{$\begin{array}{c}\text { Inisiasi } \\
\text { Menyusui } \\
\text { Dini }\end{array}$} & Frekuensi & $\%$ \\
\hline Dilakukan & 3 & $9,4 \%$ \\
\hline $\begin{array}{l}\text { Tidak } \\
\text { dilakukan }\end{array}$ & 29 & $90,6 \%$ \\
\hline Total & 32 & 100 \\
\hline
\end{tabular}

Tabel 1: Distribusi Frekuensi Responden yang Melakukan Inisiasi Menyusui Dini di Wilayah Kerja Puskesmas Lubuk Buaya Kota Padang Tahun 2010
Dari tabel 1 diatas dapat dilihat bahwa sebagian besar responden yaitu $29(90,6 \%)$ tidak melakukan inisiasi menyusui dini (IMD)

Tabel 2: Distribusi Frekuensi Gambaran Diri Primigravida di Wilayah Kerja Puskesmas Lubuk Buaya Kota Padang Tahun 2010

\begin{tabular}{|l|c|c|}
\hline Gambaran Diri & Frekuensi & $\mathbf{\%}$ \\
\hline Positif & 17 & 53,1 \\
\hline Negatif & 15 & 46,9 \\
\hline Total & 32 & 100 \\
\hline
\end{tabular}

Dari tabel 2 diatas dapat dilihat bahwa sebagian besar responden yaitu 17 $(53,1 \%)$ mempunyai gambaran diri positif.

Tabel 3: Distribusi Frekuensi Gambaran Diri Primigravida dengan Pelaksanaan Inisiasi Menyusui Dini di Wilayah Kerja Puskesmas Lubuk Buaya Kota Padang Tahun 2010

\begin{tabular}{|l|c|c|c|c|c|c|}
\hline \multirow{2}{*}{$\begin{array}{c}\text { Gambaran } \\
\text { Diri }\end{array}$} & \multicolumn{4}{|c|}{ Pelaksanaan Inisiasi Menyusui Dini } & \multicolumn{2}{c|}{ Total } \\
\cline { 2 - 7 } & \multicolumn{2}{|c|}{ Dilaksanakan } & \multicolumn{1}{|c|}{ Tidak dilaksanakan } & \multicolumn{2}{c|}{} \\
\hline Positif & 2 & $6,25 \%$ & 15 & $46,87 \%$ & 17 & $53,12 \%$ \\
\hline Negatif & 1 & $3,13 \%$ & 14 & $43,75 \%$ & 15 & $46,88 \%$ \\
\hline & 3 & $9,38 \%$ & 29 & $90,62 \%$ & 32 & $100 \%$ \\
\hline \multicolumn{7}{|c|}{$\mathrm{P}<0,05$} \\
\hline
\end{tabular}

Gambaran diri ibu primigravida lebih dari

Dari tabel 3 diatas dapat dilihat bahwa dari $3(9,38 \%)$ responden yang melaksanakan inisiasi menyusui dini, sebanyak $2(6,25 \%)$ responden yang mempunyai gambaran diri positif. Sedangkan dari 29 (90,62\%) responden yang tidak melaksanakan inisiasi menyusui dini, sebanyak 15 responden $(46,87 \%)$ mempunyai gambaran diri positif. Ini menunjukan bahwa ada hubungan gambaran diri ibu primigravida

dengan pelaksanaan inisiasi menyusui dini dimana $\mathrm{P}=0,001$ atau $\mathrm{P}<0,05$. separuh positif. Hal ini kemungkinan disebabkan karena ibu baru mengalami kehamilan yang pertama sehingga ibu menikmati perubahan-perubahan bentuk tubuhnya selama kehamilan. Ibu menganggap bahwa perubahan bentuk tubuh selama kehamilan adalah sesuatu hal yang wajar yang akan dialami oleh setiap perempuan jika memasuki masa ini. Hal ini sesuai dengan pendapat Keliat (1994) yang mengatakan bahwa pandangan yang realitis terhadap dirinya akan memberi rasa aman, sehingga terhindar dari rasa cemas dan meningkatkan harga diri. Inisiasi menyusui dini merupakan pemberian ASI kepada bayi segera setelah melahirkan. Biasanya, inisiasi menyusui dini ini 
dilakukan dalam $30-60$ menit pertama kelahiran

Pada Tabel $1 \quad$ diatas memperlihatkan bahwa dari 32 responden hanya sebagian kecil responden yaitu 3 $(9,4 \%)$ yang melakukan inisiasi menyusu dini. Angka inisiasi menyusu dini pada tabel 1 ini cukup kecil bila kita merujuk kepada konsep yang dikemukakan oleh Roesli (2008) bahwa seharusnya pelaksanaan inisiasi menyusu dini harus dilakukan pada semua persalinan. Inisiasi menyusui dini yang diberikan ini terlaksana kemungkinan karena ibu mengetahui bahwa inisiasi menyusui dini ini mempunyai banyak keuntungan.

Disamping itu, pendapat yang dikemukan oleh Lebang. MT (2009) dalam penelitian Righard \& Alade (1990) terhadap $80 \mathrm{ibu}$ yang melahirkan bahwa bayi yang diletakan di perut ibunya setelah dilahirkan akan berinisiatif sendiri untuk mencari puting susu sesegera mungkin. Pelaksanaan inisiasi menyusui dini akan lebih baik apabila ada keinginan dari ibu sendiri untuk sesegera mungkin memberikan ASInya kepada bayi apalagi dengan membiarkan bayi mencari puting susu sendiri setelah diletakan di atas perut ibu.

Adanya keinginan dari ibu sendiri untuk memberikan ASI kepada bayi sesegera mungkin, pelaksanaan inisiasi menyusui dini ini dipengaruhi oleh faktor lain seperti dukungan sosial dan pengetahuan ibu sendiri. Faktor percaya diri ibu untuk menyusui bayi juga hal penting lainnya yang harus diperhatikan. Hal ini sesuai dengan hasil penelitian yang dilakukan oleh Zaghloul dkk (2003) di Arkansas. Dimana hasil penelitian ini mengatakan bahwa beberapa faktor yang mempengaruhi tingkat inisiasi yaitu dukungan sosial, pengetahuan dan percaya diri. Semetara itu, hasil penelitian yang dilakukan oleh Deepeshwara dkk (2009) di Nepal menemukan bahwa usia ibu, pendidikan, status sosial ekonomi, pekerjaan, kehamilan dan konseling tidak mempengaruhi tindakan inisiasi menyusu dini.

Hasil analisis uji statistik pada tabel 3 diatas dapat disimpulkan bahwa dari $3 \quad(9,38 \%)$ responden yang melaksanakan inisiasi menyusui dini sebanyak $2(6,25 \%)$ responden mempunyai gambaran diri positif selama kehamilannya. Dari hasil uji statistik didapatkan bahwa $\mathrm{p}=0,001$ yang berarti bahwa ada hubungan antara gambaran diri ibu primigravida dengan pelaksanaan inisiasi menyusui dini.

Tindakan pelaksanaan inisiasi menyusui dini akan dipengaruhi oleh keadaan ibu sebelumnya seperti pandangan ibu terhadap dirinya selama kehamilan. Jika ibu berpandangan positif selama masa hamil maka perilaku berikutnya akan positif juga. Hal ini sesuai dengan teori perilaku yang dikemukan oleh Notoatmodjo (2005) yang mengatakan bahwa sikap merupakan salah satu faktor dari dalam diri seseorang yang mempengaruhi orang tersebut untuk berperilaku seperti halnya perilaku/tindakan pemberian inisiasi menyusui dini. Pendapat lain yang dikemukana oleh Karr mengatakan bahwa perilaku ataupun tindakan dipengaruhi juga oleh adanya kondisi atau situasi yang memungkinkan (action situasion) karena untuk melakukan tindakkan apa pun memang diperlukan suatu kondisi dan situasi yang tepat. Dalam hal ini seperti pada penelitian ini dimana semua ibu melahirkan secara normal dalam arti kata ibu dan bayi sehat sehingga perilaku pelaksaan inisiasi menyusui dini bisa dilakukan.

Penelitian tentang hubungan gambaran diri dengan pemberian ASI masih sedikit. Salah satu hasil penelitian ini dilakukan oleh Foster, Wilson dan Slade (1996) yang mengatakan bahwa ibu yang mempunyai gambaran diri positif selama hamil mempunyai kepuasan dalam menyusui bayinya dibandingkan memberikan susu botol kepada bayi. Hasil penelitian ini juga diperkuat oleh Stuart \& 
Suddeen (1991) yang mengatakan bahwa gambaran diri mempunyai dampak yang penting pada aspek psikologis ibu.

Hasil penelitian yang dilakukan oleh Brownell, et all (2002) pada masyarakat Afrika dan Amerika, diketahui bahwa ibu mengalami gangguan dalam menyusui setelah melahirkan karena nyeri pada payudara, merasa malu dan kurang tertarik serta takut payudara menjadi rusak karena adanya issue-issue tentang gambaran diri yang ideal sehingga banyak dari mereka yang menunda memberikan ASI. Begitu juga penelitian yang dilakukan oleh Ertem, Votto dan Leventhal (2001) bahwa masalah yang timbul selama menyusui bisa membuat ibu tidak melanjutkan menyusui seperti nyeri pada putting. Faktor lain yang menyebabkan ibu tidak mau menyusui secara dini adalah umur < 20 tahun dan tidak adanya keinginan untuk menyusui.

Fairburn, et al (1992, dalam Pitman, 2004) melakukan penelitian dengan hasil bahwa sebagian besar ibu hamil khawatir bahwa mereka tidak akan dapat mengurangi berat badan yang bertambah terus selama kehamilan. Penelitian ini juga menemukan bahwa sebagian besar ibu hamil tidak menyukai penampilan baru mereka. Begitu juga dengan Affonso, Liu-chiang dan Mayberry (1999 dalam Breslin dan Lucas, 2003) mengatakan bahwa perempuan hamil sering mengkhawatirkan perubahan penampilannya dan bagaimana harus berperilaku kepada bayi setelah melahirkan. Dalam hal ini termasuk perilaku pemberian ASI.

Pemberian ASI atau adanya keinginan ibu untuk menyusui bayinya sudah harus terlihat sejak awal kehamilan. Hal ini sesuai dengan penelitian yang dilakukan oleh Sinusas dan Gagliardi (2001); Meyes (2001) bahwa inisiatif ibu untuk menyusui sudah harus dimulai sejak awal kehamilan. Bahkan menurut Ertem, et all (2001) keputusan ibu untuk menyusui sudah harus ada sebelum hamil dan hal ini juga memperlihatkan bahwa adanya keinginan ibu untuk menyusui atas keinginan sendiri sebanyak 70,3\%. Sikap ibu terhadap gambaran diri selama hamil juga harus diperhatikan karena berpengaruh terhadap perilaku ibu seperti pemberian ASI.

Menyusui secara dini sangat dianjurkan apalagi dalam 30 menit pertama setelah melahirkan. Hal ini sangat penting karena bayi sudah merasakan lapar dan reflek hisap bayi yang paling kuat terdapat dalam fase ini (Bobak \& Jensen, 2000). Selain itu, keuntungan yang ibu dapatkan jika memberikan ASI setelah melahirkan menurut Sidi, dkk (2004) yaitu memperkuat ikatan emosional ibu-anak, memunculkan puting susu ibu yang datar atau terbenam, mencegah payudara menjadi bengkak dan mencegah mastitis.

Hal ini didukung oleh penelitian yang dilakukan oleh Rose, et all (2004) pada masyarakat Afrika-Amerika, bahwa $64 \%$ ibu mempunyai inisiatif menyusui sendiri dan $30 \%$ nya menyusui sampai usia 6 bulan. Hasil penelitian ini sudah menunjukkan suatu peningkatan dibandingkan dengan penelitian sebelumnya pada wilayah yang sama. Sedangkan hasil penelitian yang dilakukan oleh Ertem, Votto dan Leventhal (2001) hanya $27,4 \%$ ibu mau memberikan ASI atas inisiatif sendiri. Disamping itu, upaya lain untuk mendukung pelaksanaan inisiasi menyusu dini menurut Roesli (2008) adalah tenaga kesehatan yang supportif. Tenaga kesehatan inilah yang akan melaksanakan dan memberikan dorongan kepada keluarga untuk melaksanakan inisiasi menyusu dini. Apalagi pada saat ini, tindakan inisiasi menyusui dini sudah merupakan bagian dari asuhan persalinan normal (APN) dan harus dilakukan walapun kadang-kadang ada faktor yang menghambatnya.

\section{KESIMPULAN DAN SARAN}

Dari hasil penelitian dapat
disimpulkan bahwa sebagian besar
responden tidak melakukan inisiasi
menyusui dini, sebagian besar responden


mempunyai gambaran diri positif serta adanya hubungan antara gambaran diri positif pada ibu primigravida dengan tindakan pemberian inisiasi menyusui dini

Disarankan dalam pelayanan antenatal, perawat harus selalu memberikan informasi melalui pendidikan kesehatan dan penyuluhan kepada ibu hamil tentang segala hal yang berhubungan dengan kehamilan termasuk perubahan-perubahan yang terjadi selama kehamilan, dimana selama kehamilan, ibu akan mengalami perubahan fisik dan perubahan psikologis. Pada pelayanan antenatal ini, perawat juga perlu mempersiapkan ibu, suami dan keluarga dalam menghadapi masa kelahiran dan setelah persalinan melalui konseling. Agar pendidikan antenatal yang diberikan tidak berbeda, maka perlu ditetapkannya standar yang sama pada setiap praktek bidan swasta (BPS) dan rumah bersalin (RB).

\section{DAFTAR PUSTAKA}

Bianchi, A.L. (1996). The emotional health of the single mother. International Journal of Childbirth Education, 11 (2), 2223. (online)

Bobak, I.M. \& Jensen, M.D. (2000). Maternity dan ginecology nursing care. Philadelpia: W.B Saunders Company.

Brownell. K, Hutton. L, Hartman. J. \& Dabrow. S. (2002). Barrier to breastfeeding among African American adolencent mother. Clinical Pediatric, 141(9), 669673. (online)

Budiarto, E. (2004). Metodologi penelitian kedokteran. Jakarta: EGC

Burn, N. \& Grove, S.K. (2001). The practice of nursing research. $\left(4^{\text {nd }}\right.$ ed). Philadelphia: WB. Saunders Company.

Dardiri, I. (2004). Kebiasaan buruk saat hamil. Http://www.pdpersi.co.id, diambil tanggal 13 Februari 2010
Edmond, K.M; Zandoh. C, Quigley, M.A; Etogo, S.A; et all (2006). Delayed breasfeeding initiation increases risk of neonatal mortality. Pediatrics, 117(3), 905. (online)

Erlem, A.O; Votto, N. \& Laventhal, J.M. (2001). The timing and predictors of the early termination of breastfeeding. Pediatrics, 107 (3), 543.(online)

Gurnida, D. A. (2002). Hubungan antara pola menyusui dengan pendidikan, pekerjaan dan tempat bersalin ibu. Majalah Kedokteran Bandung, XXXIV (4), 114-118.

Hasyim, K.M.S; Mahyudin, N.S; Saleh, A.Z. \& Purnama, M.A.S. (2000). Pemberian air susu (ASI) eksklusif wanita pekerja perusahaan swasta kota palembang. Majalah Obstetri dan Ginekologi Indonesi. 24 (4), 246-251.

Hatta, M. (2005). ASI adalah emas yang diberikan gratis. Http//medianindonesia.com. diambil tanggal 22 Maret 2009.

Kasnodihardjo; Riyadi. S. \& Media. Y. (1998). Masalah di seputar perilaku pemberian ASI secara eksklusif. Majalah Kesehatan Masyarakat Indonesia, XXVI(3)

Keliat, B. A. (1994). Gangguan konsep diri. Jakarta: EGC

Meyers, D. (2001). Promoting and supporting breasfeeding. American academy of family physician, 64, 931-932. (online)

Murti, M. (1997). Prinsip dan metode riset epidemiologi. Yogyakarta: Gajah Mada Universty Press.

Okolo, S. N; Ade, W. Y. B. \& Okinji, M, C. (1999). Current breastfeeding knowledge, attitude and practice of mothers in five rurals communities in the savannah region. Journal of tropical pediatrics, 45 (6), 323326. (online)

Pitman, T. (2004). Your pregnance body image. Today's Parent, Pregnancy \& Birth, 4(3), 49-50. (online) 
Pratiknya, A. W. (2000). Dasar-dasar metodologi penelitian kedokteran dan kesehatan, cetakan ke tiga. Jakarta: P.T. Raja Grafindo Persada.

Rose, V. A; Warrington, V. O; Linder, R; \& Williams, C . S. (2004). Factors influencing infant feeding methode in an urban community. Thorore, 96(3), 325331. (online)

Sevilla, C. G. (1993). Pengantar metode penelitian, diterjemahkan oleh Alimuddin Tuwu. Jakarta: Penerbit Universitas Indonesia.

Soetjiningsih. (2004). Tumbuh kembang remaja dan permasalahannya. Jakarta: Sagung Seto

Stuart, G. W. \& Sundeen, S. J. (1995). Principles and practice of psychiatric nursing. St Louse: Mosby year book.

Suradi, R. (2003). Langkah-langkah menuju keberhasilan menyusui. Jakarta: Perkumpulan Perinatologi Indonesia.

Townsend, M. C. (2003). Psychiatric mental health nursing: Concepts of care. $\left(4^{\text {ed }}\right)$. Philadelphia: F.A Davis Company 